\title{
配電系統の接続変更手順決定方法
}

\begin{tabular}{|c|c|c|c|c|c|}
\hline 正 員 & 青 & 木 & 兼 & 一 & (広島累立大) \\
\hline & 奈 & 良 & 宏 & - & (広島 大) \\
\hline & & & 泰 & 司 & (広 島 \\
\hline
\end{tabular}

\section{A Re-Configuration Algorithm for Distribution Systems}

Kenichi Aoki, Member (Hiroshima Prefectural University), Koichi Nara, Member, Taiji Satoh, Member (Hiroshima University)

Recently, sectionalizing switches have been coming to be operated by remote control through the distribution SCADA system. However, the problem of determining the optimal switching sequence is a combinatorial optimization problem, and is quite difficult to solve. Hence, it is imperative to develop practically applicable solution algorithms for this problem. Several efficient algorithms have been developed for finding approximate solutions to such problems. These algorithms create a new arbitral distribution system configuration from an initial configuration, and some of these algorithms do not show a load transfer sequence to reach the objective system. Especially, there exists no systematic algorithm which shows the load transfer sequence from an emergency temporary system configuration to get back to the normal operation system. Therefore, another algorithm is necessary to find the load transfer sequence when the initial and the objective system configurations are known. Such an algorithm is proposed in this paper. The proposed algorithm finds the sub-optimal load transfer sequences based on a primal and dual effective gradient method. Several numerical examples show that the proposed algorithm is valid and effective for real scale distribution systems.

キーワード: 配電系統, 負荷切換え, 系統操作, 区間開閉器, 作業停電, 有効こう配法

\section{1.まえがき}

近年，配電系統操作自動化に伴い，事故時や作業嵉 電時の鿓荷切換え手順決定のための種々のアルゴリズ

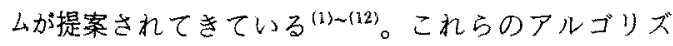
厶は電流容量制約や電在降下制約のもとで，ある系統 構成加，制約条件を満足しかつ操作目的を満足する 任意の系統構成（何らかの目的関数を最小化する場合 もある〉を求めようとするものであり，一般に組合せ 最㟶化問題になっている。ところが，例之汸事故時や 作業停電時の過渡的な系統構成を, 事故前委たは作業 停電前の系統へ切戻す場合には，現状の系統構成と目 標とする系統構成が明確によって扔り，かついずれの 系統に招いても制約違反が発生しないことが知られて
いる。このような場合には，開閉状態に変化のある開 閉器だけの操作により，上記のような複雑な切換えア ルゴリズムによるよりも簡単に目標系統へ切換えるこ とができるはずである。もちろん切庆し操作は，切換之 操作の逆順で開閉操作を行うことにより可能なことが 多い。しかし，切換え時と負荷状態が変わってしまっ ている場合などには，移行途中に制約違反が発生する ことがある。また，例夫ば損失最小の系統構成を求め るアルゴりズムなどで，最終の系統構成だけを与え， 移行手順を与党ないアルゴリズムもある ${ }^{(6)}$ 。本諭文で 提案するアルゴリズムは，このような場合に，できる 限り“状態変化のある開閉器（スイッチ）けを操 作して，現状系統加ら目標系統への移行手順を決定す るアルゴリズムである(13)。組合せ的解法を用いた同 
樣の切換手順決定アルゴリズムは，既に一部で実用に 供されているが，本手法のような制約違反解消を含む 高速かつ組織的な手法の報告はまだない。

提案する手法では, 初期状態と目標状態でスイッチ の状態 $(\mathrm{ON} / \mathrm{OFF})$ を変更しなければならないもの の数を「移行距離」として定義し，移行距離をループ 負荷切換えによって，0 まで咸少させて系統構成を変 更する。移行途中に制約違反の発生がなければ最小操 作回数は移行距離に一致する。もし，途中に制約違反 が発生する場合には，有効こう配法 ${ }^{(14)}$ の概念を用い て, 最も効果のある負荷のフィーダ間持換え（移行距 離が増加する）を行い，制約違反の発生を防いで系統 構成変更を行っている。

以下，第 2 章では配電系統に招ける開閉器操作なら びに操作時の制約について体系的に整理している。次 に，第 3 章では本論文で扱う問題を説明し，第 4 章で は過渡的に制約違反を許す場合の接続変更手順決定乃 ルゴリズム，第 5 章では制約違反の発生を認めない場 合のアルゴリズムについて説明している。更に，第 6 章では例題によって本手法の検証を行っている。

\section{2. 配電線区間開閉器の基本操作}

$\langle 2 \cdot 1\rangle$ 区間開閉器操作 配電線区間開閉器の操 作は，通常，次のような目的で行われる。

(1) 平常時

（i）損失最小化または信頼性向上のための变圧 器（またはフィーダ）間負荷切換え

（ii）作業停電操作（負荷切擙えおよび切戻し）

(2) 緊急時

(i) 事故区間除去操作

（ii）事故時負荷切換之操作

(3) 復旧時

（i）復旧時負荷切戻し操作

これらの操作は, 区間開閉器の開閉によって行われ る。基本的な開閉器操作は開か閉のいずれかであり, 開閉操作を行うときの開閉器両端の状態により, 図 1 に示すように以下の四つの操作に分類される。

(a) ループ投入（両端電源あり：閉)

(b) ループ開放（両端電源あり：開）

(c) 充電または受電（片端電源ありかつ片端電源 なし：開）

（d）停電（片端電源ありかつ両端充電あり：開） 一般の操作は, これら 4 種類の操作の組合せでなさ れる。操作の倀先順位注通常, 原則的に(b)，(c), (d)，（a）の順序である。優先順位とは, 上記 4 種類 の操作を同時に害行しなければならないと仮定するな
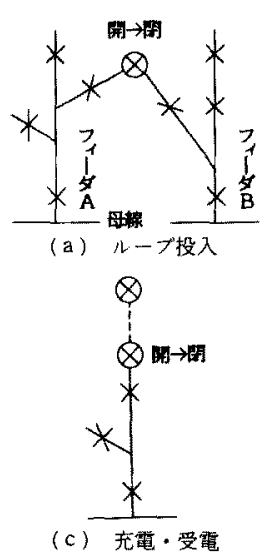
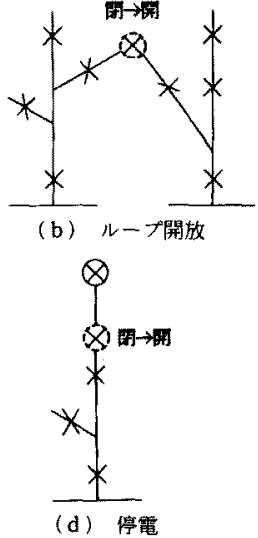

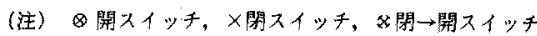

図 1 配電線区間開閉器 $の$ 基本的な操作

Fig. 1. Basic operations of sectionalizing switch.

らば，ルーブ開放を最初に実施するという意味である。 なお，（c）と（d）の操作優先順は状況により異なる。

区間開閉器はその構造上, 少なくとも片端に充電が なけ机ば操作できず，両端ともに充電がなければ “開” の状態を保持するようになっている。なお， 「充電あり」とは開閉器の当該端に単に電圧があるこ とを意味し，「電源あり」とは開閉器の当該端の延長 上に電源が接続されていることを意味している。

$\langle 2 \cdot 2\rangle$ 操作時の制約 異系統間の負荷切換え これを考慮しないものと仮定すると, 以下の制約を満 足して区間開閉器の操作を行わなけ机ばならない。

(1) 一瞬時一操作

（2）フィーダ保護のため一監視系統に指定された 数以上のループを作ってはならない

（3）電流容量制約および電圧降下制約を満足する

（4）事故区間を充電してはならない

（5）その区間の停電を目的とする場合を除いて, 充電区間を停電してはならない

上記制約のうち，（1 項は現状の遠方監視制御装置 の構造に起因する制約である。

\section{3. 接続变更手順決定問題}

いま，図 2 の例を考えよう。(a)図は現在の系統構 成である。この構成から区間井 $i$ を作業停電したいも のと仮定し上う。(b)図は, 変圧器 $(T r .2)$ の電流 容垩を考虑して適当な方法で得られた，区間\# $i$ を作 業停電した後の系統構成を示している。もし，(b)図 の系統構成を求めるときに( a )図からの移行操作手順 が与えられていれば, その手順に従って, 開閉器操作 を行えばよいが，現在提案されているすべてのアルゴ 

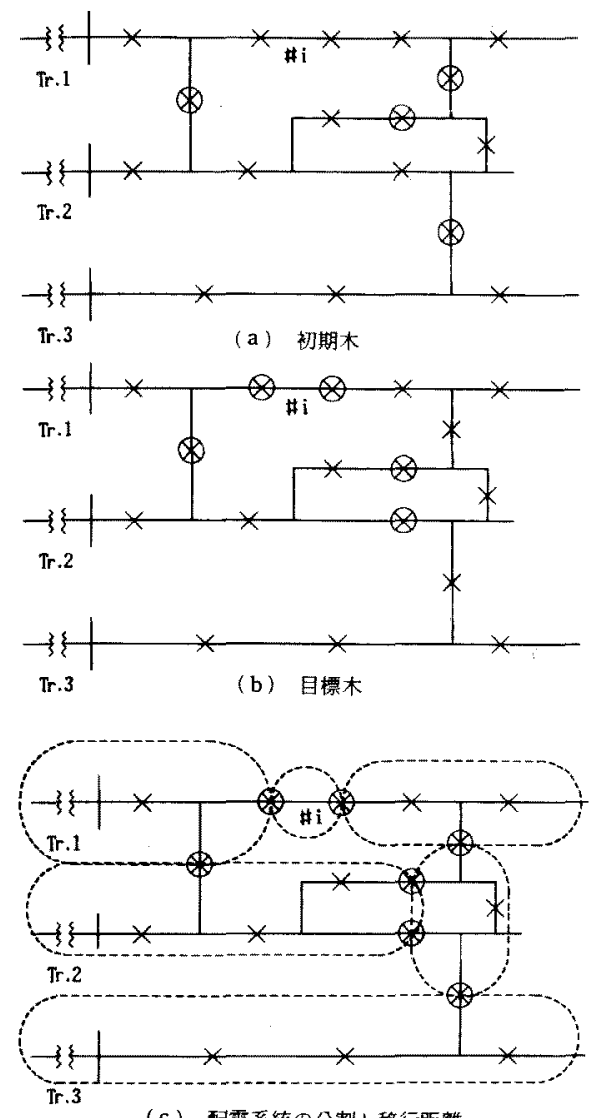

(c) 配電系統の分割上移行距離

図 2 部分系統への分割

Fig. 2. Division of distribution system.

リズムが必ずしも移行の操作手順を与えるとは限らな い。本論文の目的は，この上うな場合に初期系統構成 から目標系統構成へ，フィーダの電流容量および電圧 降下の制約条件に違反することなく移行するための開 閉器操作手順を決定するアルゴリズムを与えることで ある。対象配電線を国内で一般に採用されている常時 開放形ループ配電系統とするならば，その特徴から， 以下のことを仮定できる。

〔仮定 1〕初期系統構成およぴ目標系統構成は, いずれも制約違反のない木（Tree）構造である（説 明の便利のために，以下，前者を「初期木」，後者を 「目標木」と呼ぶことにする)。

【仮定 2〕一フィーダの木構造は, 幾つかの部分 木(Sub-tree)に分離可能であり，初期木と根(フィーダ 引出口)が同じ部分木では, 制約違反は発生しない。 なお，以下の議論では，区間負荷は力率 1.0 で平等 分布の定電流負荷であり，また配電線インピーダンス
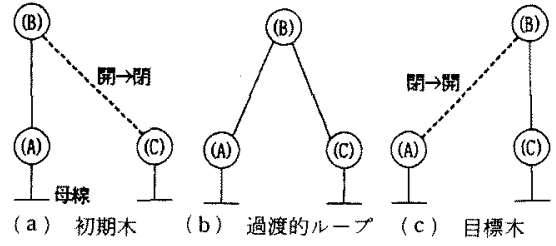

(住)——開スイッチ，……閉スイッチ

図 3 部分系統負荷の切換之

Fig. 3. Load transfer via a loop.

による位相の遅れも無視できるものと仮定している。 この仮定は必ずしも，実際とは一致しないが，現状で は区間負荷の予測自体が困難なことから，予測負荷の 大ささに思い切った割切りがあることを考皇ると，十 分満足できる仮定である。

\section{4. 過渡的な制約違反を認める場合の移行手順 決定アルゴリズム}

通常の負荷状態では，ほとんどの開開器操作におい て次の上うな仮定が成り立つ。

〔仮定 3 制約違反がない複数の同一系統内のフ イーダ (木構造) を接続してループにしても制約違反 の発生はない。または，もし仮に発生したとしても過 渡的にこれを許す。

〔仮定 1〕，(仮定 2〕ならびに〔仮定 3〕を許すと， $\langle 2 \cdot 2\rangle$ 節の操作制約も考慮して，基本的に以下の上う な方針で初期木から目標木へ移行可能になる。

（1）まず，初期木で開になっている開閉器の集合 $S_{i}$ と目標木で開になっている開閉器の集合 $S_{0}$ との全 体集合 $S\left(=S_{i} \cup S_{0}\right)$ で，全体系統を部分木に分割す る。次に，これの接続を初期木の状態から目標木の状 態へ変更する手順を見いだすことにより接続変更手順 を決定すればよい。例えば，図 2 で初期木を(a)図, 目標木を(b)図のように表すとき，(c)図のように系 統の分割を行う。な抢，ここで，開スイッチの数，す なわち $S$ の要素数が移行距離である。

（2）仮定加，もし初期木の部分木になっている 目標木 $(A)$ があり，その不足部分の全部または一部 $(B)$ を先端にもつような別の目標木またはその部分木 $(C)$ が あるならば，図3に示すように，両者をいったんルー プに接続し，部行木 $(B)$ を $(A)$ から $(C)$ へ移行して も，全体手順で制約違反は発生しない。

（3）系統保護の観点から多くのループが存在する ことは望ましくないので（2）の操作条件を満たすも のがある限り一部分木ごとにループ切換えを行う。

（4）（3)項の操作の後, 単一ループでは仮定の範 


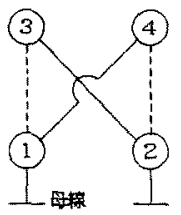

(a) 初期木

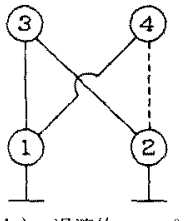

(b) 過暴的ルーフ

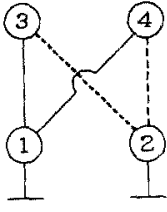

(c) 過渡的本

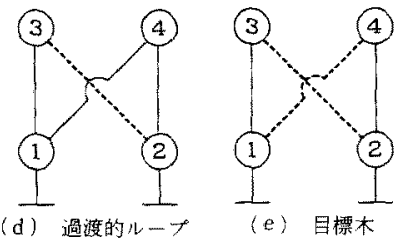

図 4 多重ループを必要とする負荷切換元

Fig. 4. Load transfer which requires multiple loop.

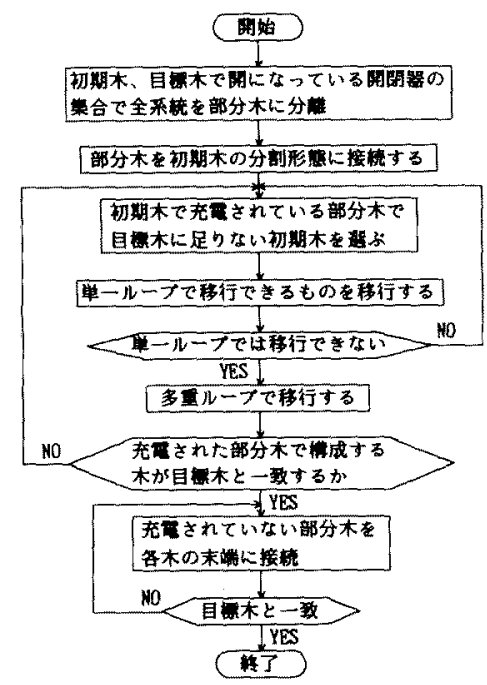

図 5 制約違反を考慮しない部分負荷 切換之手順

Fig. 5. Load transfer when no constraint violation occurs.

囲内で制約違反が発生しないことが保証されないよう なケースが発生した場合には，〔仮定 3 〕を満足するま で多重ループを構成してから，部分木の移行を行う。 例光ば，図4に扔いて，図4(a)の初期木から(e)の 目標杢まで，順に，単一ループだけで移行しようとす る場合，図 4(c)の過渡的木構成の(1)，(3)，(4)加らな る木構造は，初期木にも目標木にも，またその部分木 にも一致甘ずこの状態で制約違反が発生しないとい う保証はない。

（5）（3），(4)項の操作を繰返した後, 最後に, 初期木で充電されていなかった部分木を目標木に接続
して操作を終了できる。初期木で充電されていない区 間を除き，(3)，(4)項の操作で，必ず初期木から目 標木へ移行できることは，初期木で，いったんすべて の開閉器を閉として多重ループを作り，順次，目標木 に一致するように必要な開閉器を開としていっても 〔仮定 1〕〜仮定 3〕により許されない制約違反を吐生 しないことから明らかである。

以上の手順をまとめると，図５に示吉流れ図のよう に全体のアルゴリズムを描くことができる。

\section{5. 制約違反を認めない場合の移行手順決定 アルゴリズム}

〈5・1〉制約違反の発生と処置 通常, フィーダ に㹥十分な余裕をたせて岁るため、ループ電流が重 畳されても制約違反が発生することはない。しかし， 重負荷状態においては,ループ電流の重畳により過負 荷または電圧降下制約違反が発生する可能性がある。 すなわち，第 3 章の[仮定 3 ]の前半が必ずしも成立し ないことがある。特に，事故時の過渡的な系統構成で はこのような状洗が考えられ、ループ構成時に制約違 反の発生がないか否かを確認する必要がある。

また，保護の観点から，ループの数を制限すると第 4 章の操作によっても，負荷切換え途中に扔いて制約 違反が発生することがある。特に制約違反が発生する 可能性があるのは，以下の場合である。

(i) 2 フィーダでループを構成したとき。

(ii）多重ループを構成したとき。

(iii）多重ループを構成中にその一つを開放した とき。

負荷切換兑途中の過負荷については，過渡的である ので常時の制約上りは妕るい制約(例えば 30 分定格) を用いるのが普通である。このような制約によっても 制約違反が発生する場合には，移行距離による負荷の 移行は困難であり，いったん負荷を別のフィーダに持 換えなければならない。負荷の持換えにあたっては， 制約違反解消に必要な持換え負荷量，ならびに持換え る心゙きつィーダを決定しなければならない。以下，こ れらの決定方法について説明する。

$\langle 5 \cdot 2\rangle$ 制約違反量の計算 第 3 章の区間負荷に 関する仮定から，放射状配電線の任意の構成に扔计る 各区間電流ならびに電圧は次式から計算できる。

$$
\begin{aligned}
& I_{i t}=a_{i l} / 2+\sum_{k \in J_{j i}} a_{i k} \\
& V_{i e}=\sum_{k \in T_{e}} I_{i k} z_{i k} \\
& \text { た炈し， } I_{i l}: \text { フィーダ } i の l \text { 区間を流れる電 } \\
& \text { 流, } a_{i j}: \text { フィーダ } i \text { 区間 } j \text { の負荷電流, }
\end{aligned}
$$


$z_{i j}:$ フィーダ $i$, 区間jの線路インピーダン ス, $J_{i l}:$ フィーダiの区間 $l$ より木の葉側に ある区間の集合 $\left(l\right.$ を含まない)， $T_{e}$ ：区間 $e$ から線までの木の幹上にある区間の集 合, $V_{i e}:$ フィーダ $i$, 区間 $e$ での電圧降下 な扔, 並列コンデンサの設備がない系統では, 電圧 降下違反は放射状フィーダの末端部で, 電流容量違反 は, 変圧器, フィーダ出口ならびにフィーダ径が小さ くなる部分でのみ監視すればよいことに注意しよう。

一方，木構造系統に㧍ける負荷切換之は，負荷の瞬 時停電を避けるために、ループ切換えによって行われ る。よって, 負荷切換え時の各区間の負荷電流は, 負 荷切換光以前の睤がわかっているならばまずループ 電流を回路に重畺し，続いてループを切断したときの 切断スイッチの通過電流を逆向きに回路に重畳するこ とによって(1)，（2）式によらなくとも容易に計算で きる。ループ電流はテブナンの定理から（3)式で計算 できる。

$$
I_{100 \mathrm{p}}=\left(E_{k}-E_{l}\right) /\left(X_{k k}+X_{l l}-2 X_{k l}\right)
$$

たたし， $I_{\text {loop }}$ ：区間 $k$ と区間 $l$ を接続したと きのループ電流, $E_{i}$ : 区間 $i$ 側のスイッチ

端子電圧, $X_{i j}$ : インピーダンス行列の $i j$ 要素 なお，ループが単独の場合には，(3)式右辺の( $X_{k k}$ $\left.+X_{l t}-2 X_{k t}\right)$ はループを構成する区間のインピーダ ンスの和に等しく、インピーダンス行列によらなくと も容易に計算できることに注意されたい。

ループ時ならびにループ開放時の電流変化分から， 電圧の変化分も (4)式で容易に計算できる。

$$
V_{e, \text { new }}=V_{e, \text { old }}+\sum_{j \in T_{e}} z_{i j} \Delta I_{i j}
$$

たたし, $V_{e, \text { new }}$ ：電流変化後の区間 $e$ の電

压, $V_{e, \text { old }}$ : 電流変化前の区間 $e$ の電压,

$\Delta I_{i j}:$ フィーダ $i$, 区間 $j$ の電流変化量 以上の各式加，負荷切換六後の制約違反量を容易に 計算可能である。

〈5・3〉負荷の持換え フィーダ間の負荷の持換 えとは，初期木または目標本上りも大をい木を作って 他のフィーダの負荷を持換えることである。基本的に は，図6(a)のようにフィーダ間で相互に部分負荷の 交換を行う場合の過渡的な状態と，図 6(b)のように ループ時汇制約違反が発生するとき，そ扎を解消する ために過渡的に部分負荷を他のフィーダに移行する場 合とがある。前者では，制約違反のないフイーダどう してともに違反が発生しないように負荷の持換えを行 わなければならない。また，後者の場合は，違反のあ るフィーダ (ループ) の制約違反を解消し，かつ別の

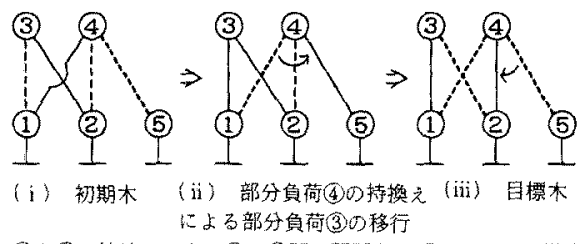

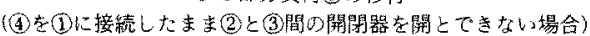

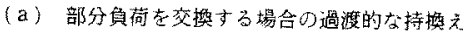

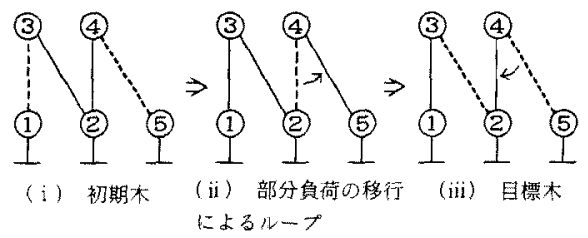

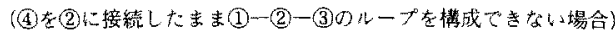

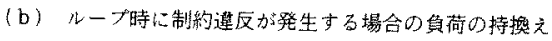

図 6 負荷の持換えパ夕ーン

Fig. 6. Patterns of load transfer.

フィーダに新たに制約違反を発生させないように負荷 の持換えを行わなければならない。

フィーダ間の負荷の持換光は系統を複雑にしないよ うに，原則として第 4 章(1)の開スイッ千集合 $S$ で 分離される部分木 (部分系統) 単位で行う。部分系統 単位による持換えが困難な場合に限り区間単位の持換 えを行う。な押, 違反解消時に限り, 多段切換え二段 までの違反解消操作を許している。また，保護の観点 からループの多重度は二重までに制限している。

（1）制約違反がない場合の持換え〔図6（a）の場 合】この場合は，一般に持換えるべき部分負荷と 持換え先が知られているので, 両フィーダに違反が発 生しなければルーブ切換えを行うことができる。も し，この持換えの結果，制約違反が発生する場合に は，ループが一重のときは二重ループによる持換えを 試みる。既に二重ループが構成されていれば他のフィ ーダへの持換えを試みなければならない。持換えは， 持換えるべき部分負荷に接続があるフィーダのうち， その負荷を持換えた後の主有効こう配が最大のフィー ダへ当該負荷を移行することによって行う。主有効こ う配 $l$ は, 制約が二つの場合の例である図 7 を参照し て次式で定義する。

$l=L / Q$

ただし，Q：部分角荷持換え後，負荷が增加 したフィーダの各監視点の電流電圧を表すべ クトルを延長して最初に監視制限值に至るま での原点からの距離, $L:$ 上記べクトルの先 端から最初に監視制限値に至るまでの距離 


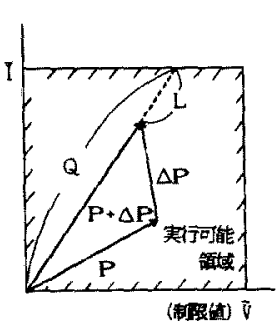

図 7 主有効こう配 Fig. 7. Primal effective gradient method.

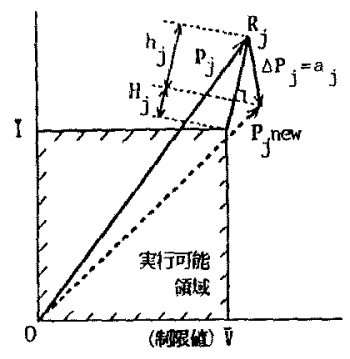

四8 双対有効こ弓配 Fig. 8. Dual effective gradient method.
（2）ループ時に制約戛反が発生する場合の負荷の 持換え[図 6(b)の場合]一般的に，複数の制約違 反が発生しているものと考光よう。この場合，他のフ イーダに制約違反を発生させないように，できる限り 小さい部分負荷を持換えることによって多くの制約違 反を解消したい。なお，持換之可能な部分負荷はルー フ上にあるものではなく，ループから出ている枝に限 られる。

（i）持換えるべき部分負荷の選択 できる限り 移動する負荷量が小さく，また制約違反の解消量が大 きい部分負荷の移動が望ましい。そのため，次の双対 有効こう配 $r$ を定義し，これが最小となる部分負荷 を移行する。

$$
r=\left(H_{j}+\beta\right) a_{j}
$$

ただし， $a_{j}$ ：部分真荷の大きさ， $H_{j}$ ：部分 負荷を移行したときの違反残量（図 8 参照） $\left(H_{j}=0\right.$ if $\left.H_{j}<0\right), \beta: H_{j}=0$ のとき $a_{j} \emptyset$ 大きさを比較するための十分小さい定数 $(0.001$ 程度 $)$

(ii）持換えフィーダの選択 ここで，(3)式て 決定された部分負荷を持換えてもらうべきフィーダを 決定しなければならないが、これは，(2)式により (1)項と同様の方法で選択できる。

〈5・4〉 解法アルゴリズム 以上の議論から, 解 法アルゴリズムを図 9 の流れ図に示すようにまとめる ことができる。

図9では，まず制約違反を生ぜずに，第 4 章の方法 で責荷移行が可能な部分負荷を先に移行する。もし， 制約違反を発生する部分負荷移行が残る場合には，発 生する違反量最大のルーブ候補加ら順に部分負荷单位 の持換えによる移行を行う。違反量最大とは，図 80 $\left|R_{j}\right|=h_{j}+H_{j}$ 最大を意味している。通常，相当複雑な 夐荷移行に机いても，ここまでの姏置で移行が終了す るが，もし以上の手順によっても制約違反が解消しな

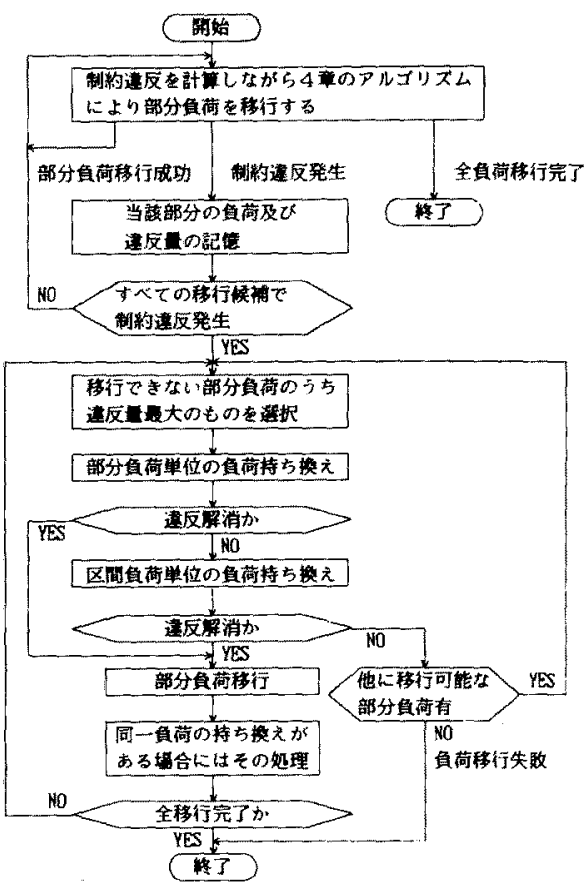

図 9 制約違反を認めない場合の移行手順 決定アルゴリズム

Fig. 9. Load transfer in which constraint violation occurence is avoided.

い場合には，双対有効こう配法による制約違反解消了 ルゴリズム(11)によって区間単位の負荷移行を行う。 これによっても制約違反が残る場合には，いったんこ の部分負荷移行を中止し，他の部分負荷移行を先に行 う。もし，すべての部分負荷移行が失敗纪終れば，こ の負荷移行は本手法では不可能ということになる。

なお，以上の手順の途中に扔いて，同一の部分負荷 をいったん他フィーダへ移行した後, 再度元の位置に 㞔すようなむだな負荷移行手順が求められる場合几 は，先の操作を行わないように手順を修正している。

\section{6. 数 值 例}

図 10 に示す 4 変圧器， 6 フィーダ, 78 負荷区間系 統に本アルゴリズムを適用した結果を示す。

図 10（a）は初期系統を，(b)図は目標系統を示し ている。なお，区間インピーダンス拉よび負荷データ は誌面の都合で省略した。いま，初期系統を損失最小 運用など何らかの理由で目標系統のように変更する必 要が生じたものと仮定しよう。初期系統加ら目標系統 への移行に際して, 計算機上で，まず，両系統のいず れか一方または両方で開になっている開閉器をすへて 


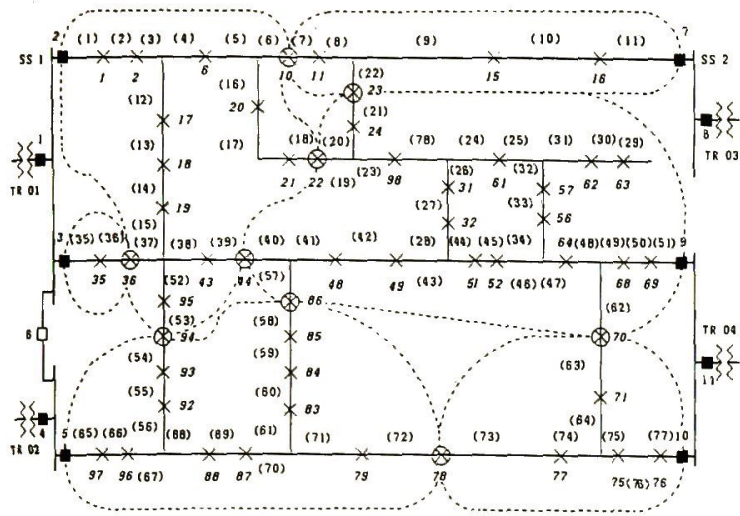

(a) 初期采統

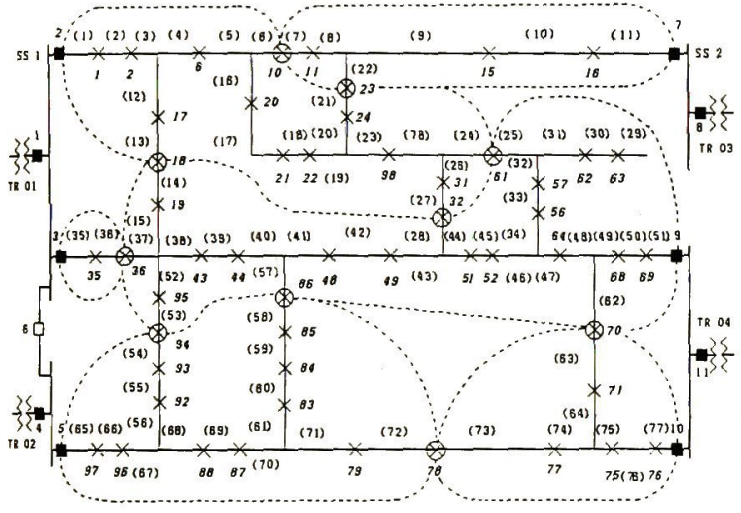

(b) 目標采統

図 10 例題系統

Fig. 10. Example distribution system.

開にすることによって 8 個の部分系統に分割する。 8 個の部分系統の初期および目標の接続状態を図 11(a)，(b)に示している。(a)図と(b)図を比較し てみると, 部分系統 3 ならびに部分系統 5 がフィーダ \#1とフィーダ\# 5 の間で交換されなければならないこ とがわかる。この場合の移行距離は 4 である。

この例は，部分系統 $3 ， 5$ ともに制約違反なしでは 移行できなく作られている。そこで，制約違反量最大 を与える部分系統 5 の移行を先に行うために，部分系 統3をフィーダ\# 2 にいったん持換え, 部分系統 5 を フィーダ\# 5 からフィーダ\# 1 に制約違反なしで移行す る。その後は, 部分系統 3 がフィーダ\# 2 からフィー ダ 5へ，これも制約違反なしで移行できる。以上で 全体の負荷移行手続きが完了したが, 移行距離 4 に対 して, 6 回の開閉器操作を必要としたことになる。 結果の開閉器操作手順を表 1 に示している。 条件を変えた他の多数の例についても計算を行っ た。その結果，ほとんどのケースが第 4 章のアルゴり
( a ) 初期木

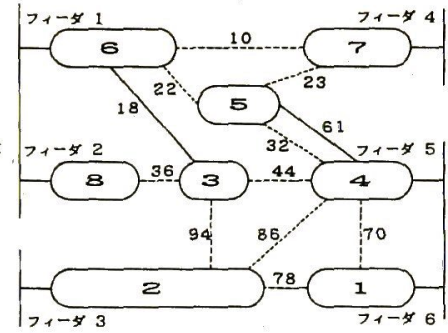

(b)目標木

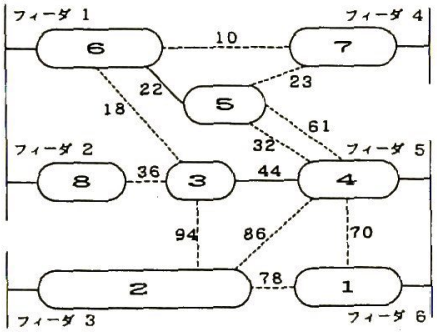

図 11 例題の部分負荷接続状態

Fig. 11. Subsystems connection of example system.

\section{表 1 開閉器操作手順}

Table 1. Resulting switching sequence.

\begin{tabular}{c|c|c||c|c|c}
\hline Number & Switch No. & ON/OFF & Number & Switch No. & ON/OFF \\
\hline 1 & 36 & ON & 4 & 61 & OFF \\
2 & 18 & OFF & 5 & 44 & ON \\
3 & 22 & ON & 6 & 36 & OFF \\
\hline
\end{tabular}

ズムで移行を完了できた。また，演算時間はいずれの ケースに扔いても APLLO DN-4000 (4MIPS) で数 秒以内であり, 本アルゴリズムの有効性を確認で きた。

\section{7.あとがき}

配電線区間開閉器の操作が自動化されるのに伴い, 現在のパターンから目標とするパターンへの切換え要 求が数多く生じるものと考えられる。その場合, 第一に 目標パターンを決めるアルゴリズム，第二には目標パ ターンだけがわかっており, その途中の負荷切換え順序 が不明の場合の切換え手順決定アルゴリズムが必要であ る。本論文は後者の目的に対するアルゴリズムを与え るものであり，自動化システムにおいて極めて日常的 に利用可能なアルゴリズムであろうと考えている。

なお, 本研究の一部は文部省科学研究費補助金（一 般研究C)の援助を受けてなされた。

(平成元年 11 月 27 日受付) 


\section{文献}

(1) Task Group on State of the Art Distribution System Design, Working Group on Distribution System Design, Distribution Subcommittee: "Bibliography on Distribution Automation, 1969-1982", IEEE Trans. Power Appara. tus Syst., PAS-103, 1176 (1984)

(2)・山田・橋本, 他：「配電線電算機制御ブログラムの開発（その 1) 一配電系統事故処理操作論理ブログラム—」, 電中研技一 研報, 74071 (昭 50)

(3) D. W. Ross, M. Carson \& A. I. Choen : "Development of Advanced Methods for Planning Electric Energy Distribution Systems". U.S. DOE Report, ET-73-C-03-1845 (1980)

(4) S. Kato, T. Naito, H. Kohno, H. Kanawa \& T. Shoji : "Computer Based Distribution Automation", IEEE PICA San Francisco (1985)

(5) C. A. Castero Jr. \& A. L. M. Franca : "Automatic Power Distribution Reconfiguration Algorithm Including Operat. ing Constraints", IFAC Electric Energy Systems, Rio de Janeiro, p. 155 (1985)

(6) K. Aoki, T. Ichimori \& M. Kanezashi : "Normal State Optimal Load Allocation in Distribution Systems", IEEE Trans. PWRD, PWRD-2, 147 (1987)

( 7 ) S. Civanlar, J. J. Grainger, et al. : "Distribution Feeder Reconfiguration for Loss Reduction", ibid., PWRD-3 1217 (1988)

(8) K. Aoki, H. Kuwabara, T. Satoh \& M. Kanezashi : "An Efficient Algorithm for Load Balancing of Transformer and Feeders by Switch Operation in Large Scale Distribu. tion System", ibid., PW RD-3, 1865 (1988)

( 9 ) C. E. Lin, et al. : "A Distribution System Outage Dispatch by Data Base Method with Real-Time Revision", ibid., PWRD-4, No. 1 (1989)

(10) A. M. Stankovic \& M. S. Calovic: "Graph Oriented Algorithm for the Steady-State Security Enhancement in Distribution Networks". ibid.. PWRD-4. No. 1 (1989)

(11) K. Aoki, K. Nara, M. Itoh. T. Satoh \& H. Kuwabara : "A New Algorithm for Service Restration in Distribution Systems". ibid.. PWRD-4. 1832 (1989)

(12) K. Aoki, K. Nara, et al. : "Totally Automated Switching Operation in Distribution System", ibid.. PWRD-5. 514 (1990)

（13）青木・奈良, 他：「配電系統の最適接続変更手順決定方法 (III)」，電気学会電力技術研資，PE-88-80（昭 63 )

（14）叟田：「プロジェクト選択と有効勾配法」オペレーション ボ・リサーチ，32、No.6（昭62)

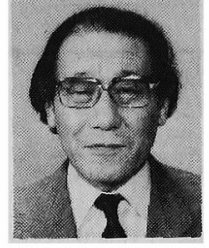

青 木 兼 一 (正員)

大正 15 年 4 月 18 日生。昭和 25 年 3 月早稲田大学理工学部電気工学 科卒業。26 年中国電力 (株) 入社, 技術研究所勤務。39年 7 月広島大 学工学部経営工学科助教授, 42 年同教授。平成元年 7 月広島県立大学教授, 経営学部長。工学博士。主と して, 電力系統, 配電系統の最適化に関する研究に従 事。日本 OR 学会フェロー, IEEE 会員。

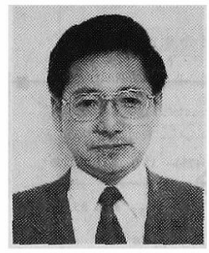

$$
\text { 奈 良宏一（正員） }
$$

昭和 20 年 8 月 20 日生。 45 年 3 月北海道大学大学院工学研究科修士 課程電気工学専攻修了。同年 4 月三 菱電機 (株) 入社。5 2 年 4 月北見工 業大学講師, 53 年 6 月同助教授を経て, 62 年 4 月よ り広島大学工学部第 2 類 (電気系) 計数管理工学講座 助教授, 現在に至る。工学博士。主として, 電力系 統, 配電系統の運用最適化に関する研究に従事。日本 OR 学会, IEEE 会員。

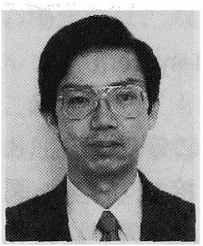

\section{佐 藤 泰 司（正員）}

昭和 32 年 12 月 14 日生。60年 3 月広島大学大学院工学研究科システ 厶工学専攻博士課程修了。同年 4 月 同大学工学部第 2 類 (電気系) 計数 管理工学講座助手, 現在に至る。工学博士。主とし て, 電力系統の運用最適化問題の研究に従事。日本 $O R$ 学会, IEEE 会員。 